\title{
Traditional Cardiovascular Risk Factors for Incident Atrial Fibrillation
}

\author{
Yoshihiro Kokubo, MD, PhD; Chisa Matsumoto, MD, PhD
}

\begin{abstract}
To prevent atrial fibrillation (AF), it is essential to reduce its risk factors and extend healthy life expectancy as a result. There are few reviews on the AF risk factors. We discuss them and approach the prevention of AF. We briefly review traditional risk factors for incident $A F$, especially focusing on high blood pressure, overweight/obesity, dyslipidemia, diabetes, tobacco smoking, and excessive drinking. When trying to prevent AF by modifying lifestyle, it is important to comprehensively utilize the risk factors for AF to predict the 10-year as an AF risk score. However, there are only 2 risk scores of AF just for the US population. There are few studies of the AF risk factors in non-Western populations. A risk score for incident AF in non-Westerners is awaited because different race and lifestyles may have different contributions as AF risk factors. An AF risk score in accordance with race could be useful for identifying persons with a high risk of AF in order to encourage them to consult a doctor and encourage lifestyle modifications before the onset of AF. (Circ J 2016; 80: 2415-2422)
\end{abstract}

Key Words: Atrial fibrillation; Epidemiology; Follow-up studies; Risk factors

A trial fibrillation (AF) is the most common cardiac arrhythmia, and it is a strong risk factor for all-cause mortality and cardiovascular disease (CVD). ${ }^{1,2}$ During the 20-year period from 1990 to 2010 , the global estimated age-adjusted prevalence rates of $\mathrm{AF}$ (/1,000 population) increased from 5.7 to 6.0 in men and from 3.6 to 3.7 in women. ${ }^{3}$ To prevent cardioembolism in patients with $\mathrm{AF}$, new oral anticoagulants are widely used as alternatives to warfarin for anticoagulation in AF patients. ${ }^{4}$ In addition, for the prevention of $\mathrm{AF}$, it is essential to reduce its risk factors and thus extend healthy life expectancy. However, the fundamental mechanisms that underlie AF are still not clearly understood. In Japan, only a limited number of prospective cohort studies of the risk factors for AF have been conducted. However, the prevalence of $\mathrm{AF}$ is also increasing in Japan., ${ }^{5,6}$ There are few reviews of the AF risk factors, therefore we discuss this topic and the approaches to AF prevention.

\section{Risk Factors for AF}

\section{Blood Pressure}

Many prospective cohort studies have demonstrated that hypertension is a strong risk factor for total death and CVD. ${ }^{7}$ Not only hypertension, ${ }^{8,9}$ but also high-normal blood pressure $(\mathrm{BP})^{10,11}$ and increasing systolic BP (SBP $)^{12}$ are risk factors for incident AF (Table 1). The Framingham Heart Study (FHS) showed that a $20-\mathrm{mmHg}$ increase in pulse pressure was associated with a 1.26 -fold increased risk of AF. ${ }^{13}$ In that study,
SBP positively associated with AF, but when diastolic BP (DBP) was added to the model, only pulse pressure was associated with AF.

In a Japanese prospective cohort study, systolic and diastolic hypertension and high pulse pressure $(\geq 60 \mathrm{mmHg})$ were suggested to be risk factors for incident $\mathrm{AF},{ }^{14}$ but after further adjustment for SBP or DBP, the associations of diastolic hypertension and high pulse pressure with incident AF were attenuated.

Elevated pulse pressure is a surrogate measure of increased proximal aortic stiffness, ${ }^{15}$ which is associated with aging. In the FHS of a cohort without antihypertensive drug use, a linear rise in SBP according to age was observed, but a concurrent early increase in DBP and decline after age 50-60 years of age were also seen, ${ }^{16}$ which is explained by the concept that increased stiffness of large arteries plays an active role in the pathophysiology of systolic hypertension. ${ }^{15}$

The underline mechanisms of hypertension that induce atrial structural remodeling remain unclear. Still, 2 mechanisms have been considered: hemodynamic change in the atria and activation of the renin-angiotensin system (RAS). Left ventricular hypertrophy and increased left atrial size are also important mediators of the relationship between BP and incident AF. ${ }^{19}$ Activating the RAS contributes to the development of AF because angiotensin II induces atrial fibrosis and hypertrophy ${ }^{17,18,20,21}$ and exerts direct cellular electrophysiological effects on cardiomyocytes. ${ }^{21}$

Received September 8, 2016; revised manuscript received October 12, 2016; accepted October 13, 2016; released online October 29, 2016

Department of Preventive Cardiology, National Cerebral and Cardiovascular Center, Suita (Y.K.); Department of Clinical Epidemiology, Hyogo College of Medicine, Nishinomiya (C.M.), Japan

Mailing address: Yoshihiro Kokubo, MD, PhD, FACC, FAHA, FESC, FESO, FJSH, Department of Preventive Cardiology, National Cerebral and Cardiovascular Center, 5-7-1 Fujishiro-dai, Suita 565-8565, Japan. E-mail: ykokubo@ @sp.ncvc.go.jp

ISSN-1346-9843 doi:10.1253/circj.CJ-16-0919

All rights are reserved to the Japanese Circulation Society. For permissions, please e-mail: cj@j-circ.or.jp 


\begin{tabular}{|c|c|c|c|c|c|c|c|}
\hline Population & Sex & $\mathbf{n}$ & $\begin{array}{c}\text { Age } \\
\text { (years) }\end{array}$ & $\begin{array}{l}\text { Follow-up } \\
\text { (years) }\end{array}$ & $\begin{array}{l}A F \\
(n)\end{array}$ & Variables & Results \\
\hline \multirow[t]{2}{*}{$\mathrm{FHS}^{8}$} & M & 2,090 & \multirow{2}{*}{$55-94$} & \multirow{2}{*}{38} & 264 & \multirow{2}{*}{ HT } & $\mathrm{OR}=1.5(1.2-2.0)$ \\
\hline & W & 2,641 & & & 298 & & $\mathrm{OR}=1.4(1.1-1.8)$ \\
\hline \multirow{3}{*}{$\begin{array}{l}\text { Southern Community } \\
\text { Cohort Study }{ }^{9}\end{array}$} & $\mathrm{M} / \mathrm{W}$ & 8,836 & $\geq 65$ & 5.7 & 1,062 & HT & OR=1.29 (1.07-1.55) \\
\hline & Black & & & & & & $\mathrm{OR}=1.37(1.05-1.80)$ \\
\hline & White & & & & & & $\mathrm{OR}=1.19(0.92-1.54)$ \\
\hline \multirow[t]{6}{*}{$\mathrm{WHS}^{10}$} & W & 34,221 & $52-65$ & 12.4 & 644 & $\mathrm{SBP}=130-139 \mathrm{mmHg}$ & $\mathrm{HR}=1.28(1.00-1.63)$ \\
\hline & & & & & & $\mathrm{SBP}=140-159 \mathrm{mmHg}$ & $\mathrm{HR}=1.56(1.22-2.01)$ \\
\hline & & & & & & $\mathrm{SBP}=160-\mathrm{mmHg}$ & $\mathrm{HR}=2.74(1.77-4.22)$ \\
\hline & & & & & & $\mathrm{DBP}=85-89 \mathrm{mmHg}$ & $\mathrm{HR}=1.53(1.05-2.23)$ \\
\hline & & & & & & $\mathrm{DBP}=90-94 \mathrm{mmHg}$ & $\mathrm{HR}=1.35(0.82-2.22)$ \\
\hline & & & & & & $\mathrm{DBP}=95-\mathrm{mmHg}$ & $\mathrm{HR}=2.15(1.21-3.84)$ \\
\hline \multirow{5}{*}{$\begin{array}{l}\text { Five governmental } \\
\text { institutions in Oslo }{ }^{11}\end{array}$} & M & 2,014 & $40-59$ & 35 & 270 & $\mathrm{SBP}=128-138 \mathrm{mmHg}$ & $\mathrm{HR}=1.98(1.22-3.27)$ \\
\hline & & & & & & $\mathrm{SBP}=140-\mathrm{mmHg}$ & $\mathrm{HR}=1.84(1.07-3.19)$ \\
\hline & & & & & & $\mathrm{DBP}=80-86 \mathrm{mmHg}$ & $\mathrm{HR}=1.67(1.00-2.85)$ \\
\hline & & & & & & $\mathrm{DBP}=88-92 \mathrm{mmHg}$ & $\mathrm{HR}=1.76(1.01-3.11)$ \\
\hline & & & & & & $\mathrm{DBP}=94-\mathrm{mmHg}$ & $\mathrm{HR}=2.36(1.38-4.15)$ \\
\hline $\mathrm{CHS}^{12}$ & $\mathrm{M} / \mathrm{W}$ & 4,844 & $\geq 65$ & 3.28 & 304 & $/ 10 \mathrm{mmHg} \mathrm{SBP}$ & $\mathrm{RR}=1.11(1.05-1.18)$ \\
\hline $\mathrm{FHS}^{13}$ & M/W & 5,331 & $35-$ & 12 & 698 & $/ 20 \mathrm{mmHg} \mathrm{PP}$ & $\mathrm{HR}=1.26(1.12-1.43)$ \\
\hline \multirow[t]{4}{*}{ Suita Study ${ }^{14}$} & $\mathrm{M} / \mathrm{W}$ & 6,906 & $30-84$ & 12.8 & 253 & Systolic HT & $\mathrm{HR}=1.74(1.22-2.49)$ \\
\hline & & & & & & Diastolic HT & $\mathrm{HR}=1.47(1.08-1.99)$ \\
\hline & & & & & & HT & $\mathrm{HR}=1.58(1.11-2.26)$ \\
\hline & & & & & & $\mathrm{PP} \geq 60 \mathrm{mmHg}$ & $\mathrm{HR}=1.75(1.17-2.64)$ \\
\hline
\end{tabular}

AF, atrial fibrillation; ARIC, Atherosclerosis Risk in Communities; CHS, Cardiovascular Health Study; DBP, diastolic blood pressure; FHS, Framingham Heart Study; HR, hazard ratio; HT, hypertension; M, men; MESA, Multi-Ethnic Study of Atherosclerosis; OR, odds ratio; PP, pulse pressure; RR, relative risk; SBP, systolic blood pressure; W, women; WHS, Women's Health Study.

\begin{tabular}{|c|c|c|c|c|c|c|c|}
\hline Population & Sex & $\mathbf{n}$ & $\begin{array}{c}\text { Age } \\
\text { (years) }\end{array}$ & $\begin{array}{l}\text { Follow-up } \\
\text { (years) }\end{array}$ & $\begin{array}{l}\text { AF } \\
(n)\end{array}$ & Variables & Results \\
\hline \multirow{4}{*}{$\begin{array}{l}\text { The Danish Diet, Cancer, and } \\
\text { Health Study }{ }^{25}\end{array}$} & $M$ & 22,482 & $50-64$ & 5.7 & 372 & Overweight & $\mathrm{HR}=1.75(1.35-2.27)$ \\
\hline & & & & & & Obesity & $\mathrm{HR}=2.35(1.70-3.25)$ \\
\hline & W & 25,107 & & & 181 & Overweight & $\mathrm{HR}=1.39(0.99-1.94)$ \\
\hline & & & & & & Obesity & $\mathrm{HR}=1.99(1.31-3.02)$ \\
\hline Suita Study ${ }^{14}$ & $\mathrm{M} / \mathrm{W}$ & 6,906 & $30-84$ & 12.8 & 253 & Overweight & $\mathrm{HR}=1.34(1.01-1.79)$ \\
\hline \multirow{2}{*}{$\begin{array}{l}\text { FHS and Framingham Offspring } \\
\text { Study }{ }^{27}\end{array}$} & $\mathrm{M} / \mathrm{W}$ & 2,384 & $57 \pm 13$ & 13.7 & 292 & Obesity & $\mathrm{HR}=1.52(1.09-2.13)$ \\
\hline & W & 2,898 & & & 234 & & $\mathrm{HR}=1.46(1.03-2.07)$ \\
\hline \multirow[t]{2}{*}{ WHS 26} & W & 34,309 & $55 \pm 7$ & 12.9 & 834 & Overweight & $\mathrm{HR}=1.22(1.02-1.45)$ \\
\hline & & & & & & Obesity & $\mathrm{HR}=1.65(1.36-2.00)$ \\
\hline
\end{tabular}

Abbreviations as in Table 1.

\section{Obesity}

During the roughly 40 years from 1975 to 2014 , the global age-standardized mean body mass index (BMI) increased from 21.7 to $24.2 \mathrm{~kg} / \mathrm{m}^{2}$ in men and from 22.1 to $24.4 \mathrm{~kg} / \mathrm{m}^{2}$ in women, and the prevalence of obesity increased from $3.2 \%$ to $10.8 \%$ in men and from $6.4 \%$ to $14.9 \%$ in women. ${ }^{22}$ Obesity is an important risk factor for death, ${ }^{23} \mathrm{CVD}^{24}$ and diabetes mellitus. $^{24}$

Being overweight ${ }^{14,25,26}$ or obese $\mathrm{e}^{25-27}$ is associated with incident AF (Table 2). Each $1 \mathrm{~kg} / \mathrm{m}^{2}$ increase in BMI is associated with an approximately 4-5\% increased risk of AF. Overweight and obesity are also related to hypertension ${ }^{28}$ and the sympathetic nervous system. ${ }^{29}$ In addition, overweight and obesity are associated with metabolic disorders. ${ }^{30}$
A case-control study shows that obesity class 3 (BMI $\geq 40 \mathrm{~kg} / \mathrm{m}^{2}$ ) is a risk factor for AF. In a hospital-based cohort study, there was an interesting finding that obesity and severe obesity are risk factors for the progression of paroxysmal to permanent $\mathrm{AF}$ (hazard ratio $(\mathrm{HR})=1.3,1.5$, respectively). ${ }^{31}$

In the Suita Study conducted in Japan, systolic prehypertensive overweight subjects and normal weight and overweight systolic hypertensive subjects were shown to have 1.7-, 1.7-, and 2.3-fold increased risk of AF, respectively, compared with normal weight normotensive subjects ( $\mathrm{P}$ for interaction between SBP and BMI=0.04). ${ }^{14}$ That study also showed that being overweight was independently linked to a 1.35-fold increased risk of AF after adjustment for both SBP and DBP. Both a high SBP and being overweight/obese independently contribute 


\begin{tabular}{|c|c|c|c|c|c|c|c|}
\hline Population & Sex & $\mathbf{n}$ & $\begin{array}{c}\text { Age } \\
\text { (years) }\end{array}$ & $\begin{array}{l}\text { Follow-up } \\
\text { (years) }\end{array}$ & $\begin{array}{l}A F \\
(n)\end{array}$ & Variables & Results \\
\hline \multirow[t]{3}{*}{ MESA and $\mathrm{FHS}^{38}$} & $\mathrm{M} / \mathrm{W}$ & 7,142 & $30-87$ & 9.6 & 480 & $\mathrm{HDL}-\mathrm{C}=40-59 \mathrm{mg} / \mathrm{dl}$ & $\mathrm{HR}=0.80(0.64-1.00)$ \\
\hline & & & & & & $\mathrm{HDL}-\mathrm{C} \geq 60 \mathrm{mg} / \mathrm{dl}$ & $\mathrm{HR}=0.66(0.50-0.91)$ \\
\hline & & & & & & $\mathrm{TG} \geq 200 \mathrm{mg} / \mathrm{dl}$ & $\mathrm{HR}=1.54(1.20-1.97)$ \\
\hline \multirow[t]{4}{*}{$\mathrm{WHS}^{39}$} & W & 23,738 & $\geq 45$ & 16.4 & 795 & Highest quintile of TC & $\mathrm{HR}=0.76(0.59-0.98)$ \\
\hline & & & & & & Highest quintile of LDL-C & $\mathrm{HR}=0.72(0.56-0.92)$ \\
\hline & & & & & & Highest quintile of VLDL-C particle & $\mathrm{HR}=0.78(0.61-0.99)$ \\
\hline & & & & & & Highest quintile of small VLDL-C & $\mathrm{HR}=0.78(0.62-0.99)$ \\
\hline \multirow[t]{2}{*}{ ARIC Study ${ }^{40}$} & $\mathrm{M} / \mathrm{W}$ & 13,969 & $45-64$ & 18.7 & 1,433 & 1-SD increase in LDL-C & $\mathrm{HR}=0.90(0.85-0.96)$ \\
\hline & & & & & & 1-SD increase in TC & $\mathrm{HR}=0.89(0.84-0.95)$ \\
\hline $\mathrm{CHS}^{12}$ & $\mathrm{M} / \mathrm{W}$ & 4,844 & $\geq 65$ & 3.28 & 304 & $1 \mathrm{mmol} / \mathrm{L}$ increase in $\mathrm{TC}$ & $\mathrm{HR}=0.86(0.76-0.98)$ \\
\hline \multirow{3}{*}{$\begin{array}{l}\text { Niigata Preventive } \\
\text { Medicine Study }{ }^{41}\end{array}$} & $\mathrm{M} / \mathrm{W}$ & 28,449 & $59 \pm 11$ & 4.5 & 265 & $10 \mathrm{mg} / \mathrm{dl}$ increase in LDL-C & $\mathrm{HR}=0.92(0.88-0.96)$ \\
\hline & & & & & & LDL-C $\geq 140 \mathrm{mg} / \mathrm{dl}$ & $H R=0.69(0.52-0.92)$ \\
\hline & & & & & & $\mathrm{HDL}-\mathrm{C}<40 \mathrm{mg} / \mathrm{dl}$ & $H R=1.58(1.00-2.48)$ \\
\hline
\end{tabular}

HDL-C, high-density lipoprotein cholesterol; LDL, low-density lipoprotein cholesterol; TC, total cholesterol; TG, triglyceride; VLDL, very lowdensity lipoprotein cholesterol. Other abbreviations as in Table 1.

\begin{tabular}{|c|c|c|c|c|c|c|c|}
\hline Population & Sex & $\mathbf{n}$ & $\begin{array}{c}\text { Age } \\
\text { (years) }\end{array}$ & $\begin{array}{l}\text { Follow-up } \\
\text { (years) }\end{array}$ & $\begin{array}{l}\text { AF } \\
(n)\end{array}$ & Variables & Results \\
\hline \multirow[t]{2}{*}{ FHS $^{8}$} & M & 2,090 & \multirow{2}{*}{$55-94$} & \multirow{2}{*}{38} & 264 & \multirow{2}{*}{ DM } & $\mathrm{OR}=1.7(1.2-2.3)$ \\
\hline & W & 2,641 & & & 298 & & $\mathrm{OR}=2.1(1.5-2.8)$ \\
\hline \multirow[t]{2}{*}{ Malmo Diet and Cancer Study ${ }^{46}$} & M & & \multirow[t]{2}{*}{$44-73$} & & & \multirow[t]{2}{*}{ History of DM } & $\mathrm{HR}=1.39(1.02-1.42)$ \\
\hline & W & & & & & & $\mathrm{HR}=1.67(1.15-2.43)$ \\
\hline \multirow{2}{*}{$\begin{array}{l}\text { Niigata Preventive Medicine } \\
\text { Study }^{48}\end{array}$} & $\mathrm{M} / \mathrm{W}$ & 28,449 & $59 \pm 11$ & 4.5 & 265 & IFG ( $(\geq 110 \mathrm{mg} / \mathrm{dl})$ & $\mathrm{HR}=1.44(1.09-1.90)$ \\
\hline & & & & & & IFG ( $(\geq 100 \mathrm{mg} / \mathrm{dl})$ & $\mathrm{HR}=1.35(1.06-1.73)$ \\
\hline
\end{tabular}

DM, diabetes mellitus; IFG, impaired fasting glucose. Other abbreviations as in Table 1.

to an increased risk of AF.

Individuals who have a high SBP and are overweight may experience exacerbation of left ventricular hypertrophy ${ }^{32,33}$ and elevated blood flow volume, ${ }^{34}$ ventricular diastolic dysfunction, ${ }^{35}$ and/or left atrial enlargement, ${ }^{36}$ and consequently a synergistically increased risk of AF.

\section{Blood Lipids}

Serum levels of high-density lipoprotein (HDL) and non-HDL cholesterols are inversely and positively established risk factors for coronary artery disease (CAD) ${ }^{37}$ However, there is limited evidence of an association between plasma lipids and $\mathrm{AF}$, with inconsistent results; in both the Multi-Ethnic Study of Atherosclerosis (MESA) and the FHS, high triglycerides and low HDL-cholesterol were associated with an increased risk of AF. ${ }^{38}$ Compared with serum levels of HDL-cholesterol $<40 \mathrm{mg} / \mathrm{dl}$ and triglycerides $<150 \mathrm{mg} / \mathrm{dl}$, the adjusted HRs for incident AF were 0.64 for HDL-cholesterol $\geq 60 \mathrm{mg} / \mathrm{dl}$ and 1.60 for triglycerides $\geq 200 \mathrm{mg} / \mathrm{dl}$. These associations were similar after adjusting for myocardial infarction (MI) and heart failure. However, there was no association between the total and LDL cholesterol levels and incident AF. In the Women's Health study and the Atherosclerotic Risk in Communities (ARIC) Study, there was an inverse association between total and LDL cholesterol levels and incident AF. ${ }^{39,40}$ The Cardiovascular Health Study (CHS) also showed that total cholesterol was inversely associated with incident AF.12 A longitudinal study of the results of health examinations in Japan revealed that total, LDL, and non-HDL cholesterol levels were inversely associated with incident AF and that HDL-cholesterol was positively associated with the incidence of AF. ${ }^{41}$

As we mentioned before (Table 3), the association between lipid levels and incident AF has been studied in several prospective population cohort studies. However, consistent results have not been obtained. Different ethnicities, lifestyles, age ranges, and study designs may partly explain the inconsistencies among the prospective studies. Low levels of HDL-cholesterol may contribute to the risk of incident AF via an increase in the prevalence of $\mathrm{CAD}$ and heart failure, which are risk factors for AF. ${ }^{42}$ HDL-cholesterol has the capacity to inhibit inflammatory mechanisms and oxidant stress, ${ }^{43}$ which may promote the development of $\mathrm{AF}^{44}$

\section{Diabetes Mellitus}

The worldwide age-standardized diabetes prevalence increased between 1980 and 2014 from $4.3 \%$ to $9.0 \%$ in men and from $5.0 \%$ to $7.9 \%$ in women. ${ }^{45}$ Type 2 diabetes mellitus (T2DM) is a risk factor for all-cause death, CVD, cancer, and Alzheimer disease. The prevention of T2DM contributes to healthy life expectancy.

In the several prospective cohort studies that have examined the relationship between T2DM and incident AF, there are inconsistent results (Table 4). The FHS showed that in men and women, T2DM presents a respective 1.7- and 2.1-fold increased risk of incident AF. ${ }^{8}$ In the Malmö Diet and Cancer study, individuals with a history of diabetes and those with 


\begin{tabular}{|c|c|c|c|c|c|c|c|}
\hline Population & Sex & $\mathbf{n}$ & $\begin{array}{c}\text { Age } \\
\text { (years) }\end{array}$ & $\begin{array}{c}\text { Follow-up } \\
\text { (years) }\end{array}$ & $\begin{array}{l}\text { AF } \\
(n)\end{array}$ & Variables & Results \\
\hline \multirow[t]{7}{*}{ ARIC study ${ }^{50}$} & $\mathrm{M} / \mathrm{W}$ & 15,329 & $45-64$ & 13.1 & 876 & Current smoking & $\mathrm{HR}=1.32(1.10-1.57)$ \\
\hline & & & & & & Former smoking & $\mathrm{HR}=2.05(1.71-2.47)$ \\
\hline & & & & & & Cigarette-years $=300-675$ & $\mathrm{HR}=1.60(1.30-1.95)$ \\
\hline & & & & & & Cigarette-years $=676-$ & $H R=2.10(1.74-2.53)$ \\
\hline & & & & & & Former cigarette-years $=800$ & $\mathrm{HR}=1.89(1.47-2.42)$ \\
\hline & & & & & & Current cigarette-years $<800$ & $\mathrm{HR}=1.85(1.49-2.30)$ \\
\hline & & & & & & Current cigarette-years $\geq 800$ & $\mathrm{HR}=2.31(1.83-2.92)$ \\
\hline \multirow[t]{2}{*}{ Rotterdam Study ${ }^{51}$} & $\mathrm{M} / \mathrm{W}$ & 5,668 & $\geq 55$ & 7.2 & 371 & Current smoking & $\mathrm{HR}=1.84(1.54-2.19)$ \\
\hline & & & & & & Former smoking & $\mathrm{HR}=1.19(0.99-1.42)$ \\
\hline
\end{tabular}

Abbreviations as in Table 1.

\begin{tabular}{|c|c|c|c|c|c|c|c|}
\hline Population & Sex & $\mathbf{n}$ & $\begin{array}{c}\text { Age } \\
\text { (years) }\end{array}$ & $\begin{array}{l}\text { Follow-up } \\
\text { (years) }\end{array}$ & $\begin{array}{l}\text { AF } \\
(\mathrm{n})\end{array}$ & Variables & Results \\
\hline \multirow[t]{2}{*}{$\begin{array}{l}\text { Danish Diet, Cancer, and } \\
\text { Health Study }{ }^{58}\end{array}$} & M & 22,528 & 56 & 5.7 & 374 & $\begin{array}{l}\text { Highest quintile } \\
\text { alcohol= } 68.7 \pm 22.8 \mathrm{~g} / \text { day }\end{array}$ & $\mathrm{HR}=1.46(1.05-2.04)$ \\
\hline & w & 25,421 & 56 & & 182 & $\begin{array}{l}\text { Highest quintile } \\
\text { alcohol }=38.8 \pm 14.8 \mathrm{~g} / \text { day }\end{array}$ & $\mathrm{HR}=1.14(0.70-1.85)$ \\
\hline \multirow{2}{*}{$\begin{array}{l}\text { The Copenhagen City } \\
\text { Heart Study }{ }^{59}\end{array}$} & M & 7,588 & & 16.3 & 548 & $\geq 35$ drinks/week & $\mathrm{HR}=1.63(1.15-2.31)$ \\
\hline & w & 8,827 & & 18.8 & 523 & $\geq 21$ drinks/week & $\mathrm{HR}=1.07(0.65-1.75)$ \\
\hline $\mathrm{WHS}^{60}$ & W & 34,715 & $\geq 45$ & 12.4 & 653 & $\geq 2$ drinks/day & $\mathrm{HR}=1.60(1.13-2.25)$ \\
\hline \multirow{3}{*}{$\begin{array}{l}\text { Circulatory Risk in } \\
\text { Communities Study }{ }^{61}\end{array}$} & $\mathrm{M} / \mathrm{W}$ & 8,602 & $30-80$ & 6.4 & 296 & Ethanol $=46-69 \mathrm{~g} /$ day & $\mathrm{HR}=1.36(0.79-2.35)$ \\
\hline & $M$ & & & & & Ethanol $>69 \mathrm{~g} /$ day & $\mathrm{HR}=2.90(1.61-5.23)$ \\
\hline & & & & & & Ethanol $>69 \mathrm{~g} /$ day & $\mathrm{HR}=3.14(1.58-6.24)$ \\
\hline
\end{tabular}

Abbreviations as in Table 1.

diabetes showed an increased risk of $\mathrm{AF}^{46}$ In other studies, diabetes and an intermediate occurrence of diabetes did not correlate with the risk of AF. ${ }^{25,47}$ A longitudinal study of the results of health examinations in Japan revealed that impaired fasting glucose was associated with increased risk of AF. ${ }^{48} \mathrm{~A}$ meta-analysis revealed that T2DM presents a weak but statistically significant increased risk of incident AF (relative risk, 1.34). ${ }^{49}$

The mechanism of the association between T2DM and AF is unclear. T2DM is a risk factor for hypertension, obesity, and $\mathrm{MI}$, and T2DM could increase the risk of AF by increasing those risk factors.

\section{Tobacco Smoking}

Smoking is a modifiable risk factor for CVD. Two prospective studies showed that smoking is a risk factor for incident AF (Table 5), ${ }^{50,51}$ but other studies showed no association. ${ }^{8,52}$ In the ARIC Study, the multivariable-adjusted HRs for AF were 1.3 in former smokers and 2.1 in current smokers, compared with never-smokers. ${ }^{50}$ In the highest tertile of accumulated amount of smoking ( $>675$ cigarette-years), the incidence of AF was 2.1-fold greater than in those who never smoked.

The Rotterdam Study indicated that both current smokers and former smokers had a 1.5-fold increased risk of AF compared with never-smokers. ${ }^{51}$ A meta-analysis revealed that current smokers and former smokers had a 1.4- and 1.2-fold increased risk of $\mathrm{AF}$, respectively, compared with neversmokers. ${ }^{52}$ That analysis also showed that $6.7 \%$ and $1.4 \%$ of the worldwide total risk of AF in men and women, respectively, was attributable to smoking. ${ }^{52}$

Some acute effect of tobacco smoking may play a role in the increased risk of AF. Cigarettes and cigars contain nicotine, which increases the heart rate, $\mathrm{BP},{ }^{53}$ and plasma catecholamines, ${ }^{54}$ and nicotine acts as a potent inhibitor of cardiac A-type $\mathrm{K}^{+}$channels, whose action contributes to the ability of nicotine to affect cardiac electrophysiology and induce arrhythmias. ${ }^{55}$ Chronic nicotine intake also contributes to the development of atrial fibrosis and atrial arrhythmias, ${ }^{56}$ and it is a risk factor for MI, pulmonary disease, and heart failure. ${ }^{57}$

\section{Alcohol Consumption}

In prospective studies of Western populations, excessive alcohol intake (60-69g ethanol/day) has been associated with a $45-46 \%$ increased risk of AF in men (Table 6), but no association between moderate alcohol consumption $(\leq 36-39 \mathrm{~g}$ ethanol/day) and the risk of AF was observed in women. ${ }^{58,59}$ In the Women's Health Study, alcohol consumption $<2$ drinks/ day was not associated with an increased risk of incident AF. ${ }^{60}$ Heavier consumption ( $\geq 2$ drinks/day) was associated with a trivial but statistically significant increased risk of AF. A Japanese cohort study showed that the adjusted HR $(95 \%$ confidence interval $[\mathrm{CI}]$ ) for incident $\mathrm{AF}$ in drinkers ( $>69 \mathrm{~g} /$ day) was 2.90 (1.61-5.23). ${ }^{61}$ In a meta-analysis, a linear regression model showed that the pooled estimate for a $10 \mathrm{~g}$ ethanol/day increment was 1.08 (95\% CI, 1.05-1.10).

Three potential reasons why excessive drinking is associated with incident AF are as follows. (1) Long-term excessive alcohol consumption could affect atrial structure and size as a 


\begin{tabular}{|c|c|c|c|c|c|}
\hline Risk factors & Study name/population & Sex & $\begin{array}{l}\text { No. of } \\
\text { subjects }\end{array}$ & $\begin{array}{c}\text { Age } \\
\text { (years) }\end{array}$ & Results \\
\hline $\begin{array}{l}\text { Coronary artery } \\
\text { disease }\end{array}$ & AMI patients (Meta-analysis) ${ }^{65}$ & $\mathrm{M} / \mathrm{W}$ & 10,053 & & $\begin{array}{l}\text { OR=2.29 }(1.96-2.67){ }^{*} \text { Killip class }>I \text { vs. Killip } \\
\text { class=I }\end{array}$ \\
\hline \multirow[t]{2}{*}{ Heart failure } & \multirow[t]{2}{*}{$\mathrm{FHS}^{8}$} & M & 2,090 & \multirow[t]{2}{*}{$55-94$} & \multirow[t]{2}{*}{ M: OR=4.5 (3.1-6.6), W: OR=5.9 (4.2-8.4) } \\
\hline & & W & 2,641 & & \\
\hline \multirow[t]{2}{*}{ Valve disease } & \multirow[t]{2}{*}{$\mathrm{FHS}^{8}$} & M & 2,090 & \multirow[t]{2}{*}{$55-94$} & \multirow[t]{2}{*}{ M: OR=1.8 (1.2-2.5), W: OR=3.4 (2.5-4.5) } \\
\hline & & W & 2,641 & & \\
\hline \multirow{4}{*}{$\begin{array}{l}\text { Chronic kidney } \\
\text { disease }\end{array}$} & \multirow[t]{4}{*}{ ARIC Study ${ }^{66}$} & \multirow[t]{4}{*}{$\mathrm{M} / \mathrm{W}$} & \multirow[t]{4}{*}{10,328} & \multirow[t]{4}{*}{$45-64$} & eGFR=60-89: HR=1.3 (1.1-1.6) \\
\hline & & & & & eGFR=30-59: HR=1.6 (1.3-2.1) \\
\hline & & & & & eGFR=15-29: HR=3.2 (2.0-5.0) \\
\hline & & & & & $\begin{array}{l}\text { Macroalbuminuria }(A C R \geq 300 \text { and } 30-299 \mathrm{mg} / \mathrm{g}) \\
\mathrm{HR}=3.2(2.3-4.5) \text { and } 2.0(1.6-2.4)\end{array}$ \\
\hline $\begin{array}{l}\text { Sleep apnea } \\
\text { syndrome }\end{array}$ & Patients attending a sleep clinic ${ }^{69}$ & $\mathrm{M} / \mathrm{W}$ & 6,841 & $48.3 \pm 12.5$ & $\mathrm{AHI}>5 / \mathrm{h}: \mathrm{HR}=1.55(1.21-2.00)$ \\
\hline $\begin{array}{l}\text { Non-alcoholic fatty } \\
\text { liver disease }\end{array}$ & $\begin{array}{l}\text { OPERA (Oulu Project Elucidating } \\
\text { Risk of Atherosclerosis) }\end{array}$ & & 958 & & $\mathrm{OR}=1.88(1.03-3.45)$ \\
\hline Cancer & $\begin{array}{l}\text { Reasons for Geographic And } \\
\text { Racial Differences Stroke }\end{array}$ & $\mathrm{M} / \mathrm{W}$ & 15,428 & $66 \pm 8.9$ & $\mathrm{OR}=1.19(1.02-1.38)$ \\
\hline \multirow{3}{*}{$\begin{array}{l}\text { Impaired-media } \\
\text { thickness }\end{array}$} & ARIC study ${ }^{73}$ & $\mathrm{M} / \mathrm{W}$ & 13,907 & & cIMT: per 1-SD: HR=1.12 (1.08-1.16) \\
\hline & MESA study & $\mathrm{M} / \mathrm{W}$ & 6,640 & & \multirow[t]{2}{*}{ Carotid plaque: $\mathrm{HR}=1.30$ (1.19-1.42) } \\
\hline & Rotterdam study & $\mathrm{M} / \mathrm{W}$ & 5,220 & & \\
\hline \multirow[t]{3}{*}{ Arterial stiffness } & ARIC study ${ }^{73}$ & $\mathrm{M} / \mathrm{W}$ & 13,907 & & \multirow[t]{3}{*}{ PWV: HR per 1-SD increment=1.15 (1.03-1.29) } \\
\hline & MESA study & $\mathrm{M} / \mathrm{W}$ & 6,640 & & \\
\hline & Rotterdam study & $\mathrm{M} / \mathrm{W}$ & 5,220 & & \\
\hline $\begin{array}{l}\text { Left ventricular } \\
\text { diastolic function }\end{array}$ & $\mathrm{FHS}^{72}$ & $\mathrm{M} / \mathrm{W}$ & 942 & 75 & $\begin{array}{l}\text { Per 1-SD increment in VTI E/A: HR=1.28 (1.02- } \\
\text { 1.59) }\end{array}$ \\
\hline Family history & Framingham Offspring Study ${ }^{68}$ & $\mathrm{M} / \mathrm{W}$ & 2,243 & $\leq 30$ & $\begin{array}{l}\text { At least } 1 \text { parent with history of } \mathrm{AF}: \mathrm{OR}=1.85 \\
(1.12-3.06)\end{array}$ \\
\hline Low birth weight & WHS 67 & W & 27,982 & $>45$ years & $\begin{array}{l}\text { Birth weight categories }(3.9-4.5 \text { and }>4.5 \mathrm{~kg}): \\
\mathrm{HR}=1.70(1.23-2.37) \text { and } 1.71(1.12-2.61)(P \\
\text { for linear trend=0.002) }\end{array}$ \\
\hline \multirow[t]{4}{*}{ Exercise } & \multirow[t]{2}{*}{ Swedish Mammography Cohort ${ }^{77}$} & \multirow[t]{2}{*}{ W } & \multirow[t]{2}{*}{36,513} & \multirow[t]{2}{*}{$49-83$} & $\begin{array}{l}\text { Leisure-time exercise: RR=0.85 (0.75-0.95) for } \\
\geq 4 \mathrm{~h} / \text { week vs. }<1 \mathrm{~h} / \text { week) }\end{array}$ \\
\hline & & & & & $\begin{array}{l}\text { Walking/bicycling: } R R=0.81(0.72-0.92) \text { for } \\
\geq 40 \mathrm{~min} / \text { day vs. almost never }\end{array}$ \\
\hline & \multirow[t]{2}{*}{ Physicians' Health Study ${ }^{79}$} & \multirow[t]{2}{*}{ M } & \multirow[t]{2}{*}{16,921} & & $\begin{array}{l}\text { With increasing frequency of vigorous exercise } \\
(0,1,1-2,3-4,5-7 \text { days/week) } R R=1.0 \text { (refer- } \\
\text { ent), } 0.90,1.09,1.04 \text {, and } 1.20(P=0.04)\end{array}$ \\
\hline & & & & & $\begin{array}{l}\text { Men }<50 \text { years of age }(1.0,0.94,1.20,1.05, \\
1.74, P<0.01) \text { and joggers }(1.0,0.91,1.03,1.30 \\
1.53, P<0.01)\end{array}$ \\
\hline Uric acid & Meta-analysis ${ }^{74}$ & $\mathrm{M} / \mathrm{W}$ & 138,306 & & High UA: RR=1.67 (1.23-2.27) \\
\hline \multirow[t]{2}{*}{ Fish intake } & \multirow[t]{2}{*}{$\mathrm{FHS}^{78}$} & \multirow[t]{2}{*}{$\mathrm{M} / \mathrm{W}$} & \multirow[t]{2}{*}{4,815} & \multirow[t]{2}{*}{$\geq 65$} & Intake 1-4times/week HR=0.72 $(0.58-0.91)$ \\
\hline & & & & & Intake $>5$ times/week HR=0.69 $(0.52-0.91)$ \\
\hline Sleep duration & Physicians' Health Study ${ }^{80}$ & M & 18,755 & $67.7 \pm 8.6$ & $\begin{array}{l}\mathrm{HR}=1.13(1.00-1.27) \text { for greatest category of } \\
\text { sleep duration }\end{array}$ \\
\hline $\begin{array}{l}\text { B-type natriuretic } \\
\text { peptide }\end{array}$ & $\mathrm{FHS}^{75}$ & $\mathrm{M} / \mathrm{W}$ & 120 & $58.4 \pm 9.7$ & $\begin{array}{l}\text { Log-transformed BNP/1-SD: HR=1.62 (1.41- } \\
1.85)\end{array}$ \\
\hline Troponin T & ARIC Study ${ }^{76}$ & $\mathrm{M} / \mathrm{W}$ & 10,584 & 62.7 & $\begin{array}{l}\text { 1-SD difference in log transformed troponin } \mathrm{T} \text { : } \\
\mathrm{HR}=1.16(1.10-1.23)\end{array}$ \\
\hline
\end{tabular}

ACR, albumin-to-creatinine ratio; AHI, apnea/hypopnea index; AMI, acute myocardial infarction; cIMT, carotid intima-media thickness; eGFR, estimated glomerular filtration rate; PMV, pulse wave velocity; RR, relative risk. Other abbreviations as in Table 1.

direct cardiotoxin, which was shown in a rat experiment, ${ }^{62}$ and it may also have direct proarrhythmic effects. ${ }^{63}$ (2) Excessive drinking is linked to an increased risk of hypertension, ${ }^{64}$ which is a risk factor for AF. ${ }^{10,11,14}$

\section{Other Risk Factors}

As well as the traditional risk factors for incident AF, there are several other risk factors (Table 7), but further studies of these factors are awaited. Killip class $>\mathrm{I}$ in acute $\mathrm{MI},{ }^{65}$ congestive heart failure, valve disease,${ }^{8}$ reduced kidney function, presence of albuminuria, ${ }^{66}$ birth weight ${ }^{67}$ presence of parental AF, ${ }^{68}$ obstructive sleep apnea, ${ }^{69}$ non-alcoholic fatty liver disease, ${ }^{70}$ and a history of non-life-threatening cancer $^{71}$ may be also associated with incident AF.

Increased velocity-time integrals $\mathrm{E} / \mathrm{A},{ }^{72}$ high carotid intimamedia thickness, high arterial stiffness, ${ }^{73}$ urinary acid, ${ }^{74} \mathrm{~B}$-type 
natriuretic peptide, ${ }^{75}$ and high-sensitivity cTnT levels ${ }^{76}$ are markers of increased risk of AF. As for lifestyle factors, physical activity ${ }^{77}$ and fish intake ${ }^{78}$ are inversely associated with a risk of AF. However, heavy exercise was associated with an increased risk of incident $\mathrm{AF}$ in young men and joggers. ${ }^{79}$ Long sleep duration is associated with a modestly elevated risk of AF among US men. ${ }^{80}$

\section{AF Risk Score}

It is very important that a scoring system based on community-based cohorts is used to predict an individual's absolute risk of incident $\mathrm{AF}$ occurring within the next 10 years, based on the individual's cardiovascular risk factors identified in primary care. However, only 2 studies that examined a risk score of incident AF are currently available. The ARIC study demonstrated that $56.5 \%$ of incident AF could be attributed to common cardiovascular risk factors, including hypertension, obesity, T2DM, and smoking. ${ }^{81}$ The Framingham study used a risk score for incident $\mathrm{AF}$ that included the factors of age, sex, BMI, SBP, treatment for hypertension, PR interval, clinically significant cardiac murmur, and congestive heart failure; the additional incorporation of echocardiographic measurements only slightly improved the predictive ability of this risk score. ${ }^{42}$ Recently, in a Japanese general urban population, a risk score for incident $\mathrm{AF}$ has been developed to predict individuals' absolute risk of incident AF. ${ }^{82}$

\section{Conclusions}

We briefly reviewed the primary traditional risk factors for incident AF, including high BP, obesity, dyslipidemia, diabetes, tobacco smoking, excessive drinking, and other risk factors. Prevention of AF in clinical practice and conducting lifestyle modification programs to prevent AF require clinicians to utilize these risk factors comprehensively to predict an individual's 10-year risk of AF. For that reason, it is essential to have a clinical risk score for AF that can accurately predict the risk. However, there are only 2 risk scores for AF, both of which were designed for the US population. Development of a risk score for incident AF in non-Westerners, especially in the Suita Study, is awaited.

\section{Disclosures}

None.

\section{Sources of Funding}

This work was supported by the Intramural Research Fund of the National Cerebral and Cardiovascular Center, by the Japan Agency for Medical Research and development, AMED (15 gk0210001 h0101), the Practical Research Project for Life-Style related Diseases including Cardiovascular Diseases and Diabetes Mellitus from Japan Agency for Medical Research and Development, AMED (15656344), and by a Grant-in-Aid for Scientific Research (B, No. 16H05252) and Challenging Exploratory Research (No. 16K15365) in Japan.

\section{References}

1. Healey JS, Oldgren J, Ezekowitz M, Zhu J, Pais P, Wang J, et al. Occurrence of death and stroke in patients in 47 countries 1 year after presenting with atrial fibrillation: A cohort study. Lancet 2016; 388: $1161-1169$.

2. Emdin CA, Wong CX, Hsiao AJ, Altman DG, Peters SA, Woodward M, et al. Atrial fibrillation as risk factor for cardiovascular disease and death in women compared with men: Systematic review and meta-analysis of cohort studies. BMJ 2016; 532: h7013.

3. Chugh SS, Havmoeller R, Narayanan K, Singh D, Rienstra M, Benjamin EJ, et al. Worldwide epidemiology of atrial fibrillation: A
Global Burden of Disease 2010 Study. Circulation 2014; 129: $837-$ 847.

4. Kokubo Y. New oral anticoagulants (NOAC) studies in the ideal and the real world: Needs of prospective observational studies. Circ $J$ 2015; 79: 962-963.

5. Inoue H, Fujiki A, Origasa H, Ogawa S, Okumura K, Kubota I, et al. Prevalence of atrial fibrillation in the general population of Japan: An analysis based on periodic health examination. Int J Cardiol 2009; 137: 102-107.

6. Ohsawa M, Okayama A, Sakata K, Kato K, Itai K, Onoda T, et al. Rapid increase in estimated number of persons with atrial fibrillation in Japan: An analysis from national surveys on cardiovascular diseases in 1980, 1990 and 2000. J Epidemiol 2005; 15: 194-196.

7. Heerspink HJ, Ninomiya T, Zoungas S, de Zeeuw D, Grobbee DE, Jardine MJ, et al. Effect of lowering blood pressure on cardiovascular events and mortality in patients on dialysis: A systematic review and meta-analysis of randomised controlled trials. Lancet 2009; 373: $1009-1015$.

8. Benjamin EJ, Levy D, Vaziri SM, D’Agostino RB, Belanger AJ, Wolf PA. Independent risk factors for atrial fibrillation in a population-based cohort: The Framingham Heart Study. JAMA 1994; 271: $840-844$.

9. Lipworth L, Okafor H, Mumma MT, Edwards TL, Roden DM, Blot WJ, et al. Race-specific impact of atrial fibrillation risk factors in blacks and whites in the southern community cohort study. Am J Cardiol 2012; 110: 1637-1642.

10. Conen D, Tedrow UB, Koplan BA, Glynn RJ, Buring JE, Albert $\mathrm{CM}$. Influence of systolic and diastolic blood pressure on the risk of incident atrial fibrillation in women. Circulation 2009; 119: $2146-$ 2152.

11. Grundvold I, Skretteberg PT, Liestol K, Erikssen G, Kjeldsen SE, Arnesen $\mathrm{H}$, et al. Upper normal blood pressures predict incident atrial fibrillation in healthy middle-aged men: A 35-year follow-up study. Hypertension 2012; 59: 198-204.

12. Psaty BM, Manolio TA, Kuller LH, Kronmal RA, Cushman M, Fried $\mathrm{LP}$, et al. Incidence of and risk factors for atrial fibrillation in older adults. Circulation 1997; 96: 2455-2461.

13. Mitchell GF, Vasan RS, Keyes MJ, Parise H, Wang TJ, Larson MG, et al. Pulse pressure and risk of new-onset atrial fibrillation. JAMA 2007; 297: 709-715.

14. Kokubo Y, Watanabe M, Higashiyama A, Nakao YM, Kobayashi T, Watanabe $\mathrm{T}$, et al. Interaction of blood pressure and body mass index with risk of incident atrial fibrillation in a Japanese urban cohort: The Suita Study. Am J Hypertens 2015; 28: 1355-1361.

15. Mitchell GF, Lacourciere Y, Ouellet JP, Izzo JL Jr, Neutel J, Kerwin $\mathrm{LJ}$, et al. Determinants of elevated pulse pressure in middle-aged and older subjects with uncomplicated systolic hypertension: The role of proximal aortic diameter and the aortic pressure-flow relationship. Circulation 2003; 108: 1592-1598.

16. Franklin SS, Gustin W 4th, Wong ND, Larson MG, Weber MA, Kannel WB, et al. Hemodynamic patterns of age-related changes in blood pressure: The Framingham Heart Study. Circulation 1997; 96: 308-315.

17. McEwan PE, Gray GA, Sherry L, Webb DJ, Kenyon CJ. Differential effects of angiotensin II on cardiac cell proliferation and intramyocardial perivascular fibrosis in vivo. Circulation 1998; 98: $2765-$ 2773.

18. Seccia TM, Belloni AS, Kreutz R, Paul M, Nussdorfer GG, Pessina $\mathrm{AC}$, et al. Cardiac fibrosis occurs early and involves endothelin and AT-1 receptors in hypertension due to endogenous angiotensin II. $J$ Am Coll Cardiol 2003; 41: 666-673.

19. Wang L, Jerosch-Herold M, Jacobs DR Jr, Shahar E, Detrano R, Folsom AR, et al. Coronary artery calcification and myocardial perfusion in asymptomatic adults: The MESA (Multi-Ethnic Study of Atherosclerosis). J Am Coll Cardiol 2006; 48: 1018-1026.

20. Goette A, Lendeckel U. Electrophysiological effects of angiotensin II. Part I: Signal transduction and basic electrophysiological mechanisms. Europace 2008; 10: 238-241.

21. Ehrlich JR, Hohnloser SH, Nattel S. Role of angiotensin system and effects of its inhibition in atrial fibrillation: Clinical and experimental evidence. Eur Heart J 2006; 27: 512-518.

22. NCD Risk Factor Collaboration (NCD-RisC). Trends in adult bodymass index in 200 countries from 1975 to 2014: A pooled analysis of 1698 population-based measurement studies with 19.2 million participants. Lancet 2016; 387: 1377-1396.

23. Berrington de Gonzalez A, Hartge P, Cerhan JR, Flint AJ, Hannan $\mathrm{L}$, MacInnis RJ, et al. Body-mass index and mortality among 1.46 million white adults. N Engl J Med 2010; 363: 2211-2219.

24. Singh GM, Danaei G, Farzadfar F, Stevens GA, Woodward M, Wormser D, et al. The age-specific quantitative effects of metabolic 
risk factors on cardiovascular diseases and diabetes: A pooled analysis. PLoS One 2013; 8: e65174, doi:10.1371/journal.pone.0065174

25. Frost L, Hune LJ, Vestergaard P. Overweight and obesity as risk factors for atrial fibrillation or flutter: The Danish Diet, Cancer, and Health Study. Am J Med 2005; 118: 489-495.

26. Tedrow UB, Conen D, Ridker PM, Cook NR, Koplan BA, Manson $\mathrm{JE}$, et al. The long- and short-term impact of elevated body mass index on the risk of new atrial fibrillation the WHS (Women's Health Study). J Am Coll Cardiol 2010; 55: 2319-2327.

27. Wang TJ, Parise H, Levy D, D' Agostino RB Sr, Wolf PA, Vasan RS, et al. Obesity and the risk of new-onset atrial fibrillation. JAMA 2004; 292: 2471-2477.

28. de Simone G, Devereux RB, Chinali M, Roman MJ, Best LG, Welty $\mathrm{TK}$, et al. Risk factors for arterial hypertension in adults with initial optimal blood pressure: The Strong Heart Study. Hypertension 2006; 47: $162-167$

29. Landsberg L, Aronne LJ, Beilin LJ, Burke V, Igel LI, Lloyd-Jones $\mathrm{D}$, et al. Obesity-related hypertension: Pathogenesis, cardiovascular risk, and treatment: A position paper of the Obesity Society and the American Society of Hypertension. J Clin Hypertens (Greenwich) 2013; 15: $14-33$.

30. Zois NE, Bartels ED, Hunter I, Kousholt BS, Olsen LH, Goetze JP. Natriuretic peptides in cardiometabolic regulation and disease. Nat Rev Cardiol 2014; 11: 403-412.

31. Tsang TS, Barnes ME, Miyasaka Y, Cha SS, Bailey KR, Verzosa $\mathrm{GC}$, et al. Obesity as a risk factor for the progression of paroxysmal to permanent atrial fibrillation: A longitudinal cohort study of 21 years. Eur Heart J 2008; 29: 2227-2233.

32. Cuspidi C, Rescaldani M, Sala C, Grassi G. Left-ventricular hypertrophy and obesity: A systematic review and meta-analysis of echocardiographic studies. J Hypertens 2014; 32: 16-25.

33. Alaud-din A, Meterissian S, Lisbona R, MacLean LD, Forse RA. Assessment of cardiac function in patients who were morbidly obese. Surgery 1990; 108: 809-818; discussion 818-820.

34. Kenny J, Plappert T, Sutton MS. Relationship between instantaneous trans-mitral blood flow velocity and instantaneous left ventricular volume in normal and hypertrophied hearts. Int J Cardiol 1991; 33: $133-140$.

35. Iacobellis G, Ribaudo MC, Leto G, Zappaterreno A, Vecci E, Di Mario U, et al. Influence of excess fat on cardiac morphology and function: Study in uncomplicated obesity. Obes Res 2002; 10: 767 773

36. Bode F, Katchman A, Woosley RL, Franz MR. Gadolinium decreases stretch-induced vulnerability to atrial fibrillation. Circulation 2000; 101: 2200-2205.

37. Emerging Risk Factors Collaboration, Di Angelantonio E, Sarwar N, Perry P, Kaptoge S, Ray KK, Thompson A, et al. Major lipids, apolipoproteins, and risk of vascular disease. JAMA 2009; 302: 1993 2000.

38. Alonso A, Yin X, Roetker NS, Magnani JW, Kronmal RA, Ellinor PT, et al. Blood lipids and the incidence of atrial fibrillation: The Multi-Ethnic Study of Atherosclerosis and the Framingham Heart Study. J Am Heart Assoc 2014; 3: e001211, doi:10.1161/JAHA.114 001211.

39. Mora S, Akinkuolie AO, Sandhu RK, Conen D, Albert CM. Paradoxical association of lipoprotein measures with incident atrial fibrillation. Circ Arrhythm Electrophysiol 2014; 7: 612-619.

40. Lopez FL, Agarwal SK, Maclehose RF, Soliman EZ, Sharrett AR, Huxley RR, et al. Blood lipid levels, lipid-lowering medications, and the incidence of atrial fibrillation: The atherosclerosis risk in communities study. Circ Arrhythm Electrophysiol 2012; 5: 155-162.

41. Watanabe H, Tanabe N, Yagihara N, Watanabe T, Aizawa Y, Kodama M. Association between lipid profile and risk of atrial fibrillation. Circ J 2011; 75: 2767-2774.

42. Schnabel RB, Sullivan LM, Levy D, Pencina MJ, Massaro JM, D'Agostino RB Sr, et al. Development of a risk score for atrial fibrillation (Framingham Heart Study): A community-based cohort study. Lancet 2009; 373: 739-745.

43. Rye KA, Barter PJ. Cardioprotective functions of HDLs. J Lipid Res 2014; 55: $168-179$.

44. Van Wagoner DR. Oxidative stress and inflammation in atrial fibrillation: Role in pathogenesis and potential as a therapeutic target. $J$ Cardiovasc Pharmacol 2008; 52: 306-313.

45. NCD Risk Factor Collaboration (NCD-RisC). Worldwide trends in diabetes since 1980: A pooled analysis of 751 population-based studies with 4.4 million participants. Lancet 2016; 387: 1513-1530.

46. Smith JG, Platonov PG, Hedblad B, Engstrom G, Melander O. Atrial fibrillation in the Malmo Diet and Cancer study: A study of occurrence, risk factors and diagnostic validity. Eur J Epidemiol 2010; 25: $95-102$.
47. Rosengren A, Hauptman PJ, Lappas G, Olsson L, Wilhelmsen L, Swedberg K. Big men and atrial fibrillation: Effects of body size and weight gain on risk of atrial fibrillation in men. Eur Heart $J$ 2009; 30: $1113-1120$.

48. Watanabe H, Tanabe N, Watanabe T, Darbar D, Roden DM, Sasaki $\mathrm{S}$, et al. Metabolic syndrome and risk of development of atrial fibrillation: The Niigata preventive medicine study. Circulation 2008; 117: $1255-1260$.

49. Huxley RR, Filion KB, Konety S, Alonso A. Meta-analysis of cohort and case-control studies of type 2 diabetes mellitus and risk of atrial fibrillation. Am J Cardiol 2011; 108: 56-62.

50. Chamberlain AM, Agarwal SK, Folsom AR, Duval S, Soliman EZ, Ambrose M, et al. Smoking and incidence of atrial fibrillation: Results from the Atherosclerosis Risk in Communities (ARIC) study. Heart Rhythm 2011; 8: 1160-1166.

51. Heeringa J, Kors JA, Hofman A, van Rooij FJ, Witteman JC. Cigarette smoking and risk of atrial fibrillation: The Rotterdam Study. Am Heart J 2008; 156: $1163-1169$.

52. Zhu W, Yuan P, Shen Y, Wan R, Hong K. Association of smoking with the risk of incident atrial fibrillation: A meta-analysis of prospective studies. Int J Cardiol 2016; 218: 259-266.

53. Benowitz NL, Jacob P 3rd, Jones RT, Rosenberg J. Interindividual variability in the metabolism and cardiovascular effects of nicotine in man. J Pharmacol Exp Ther 1982; 221: 368-372.

54. Haass M, Kubler W. Nicotine and sympathetic neurotransmission. Cardiovasc Drugs Ther 1997; 10: 657-665.

55. Wang H, Shi H, Zhang L, Pourrier M, Yang B, Nattel S, et al. Nicotine is a potent blocker of the cardiac A-type $\mathrm{K}(+)$ channels: Effects on cloned $\mathrm{Kv} 4.3$ channels and native transient outward current. Circulation 2000; 102: 1165-1171.

56. Goette A, Lendeckel U, Kuchenbecker A, Bukowska A, Peters B, Klein HU, et al. Cigarette smoking induces atrial fibrosis in humans via nicotine. Heart 2007; 93: 1056-1063.

57. Huxley RR, Barzi F, Woo J, Giles G, Lam TH, Rahimi K, et al. A comparison of risk factors for mortality from heart failure in Asian and non-Asian populations: An overview of individual participant data from 32 prospective cohorts from the Asia-Pacific Region. BMC Cardiovasc Disord 2014; 14: 61.

58. Frost L, Vestergaard P. Alcohol and risk of atrial fibrillation or flutter: A cohort study. Arch Intern Med 2004; 164: 1993-1998.

59. Mukamal KJ, Tolstrup JS, Friberg J, Jensen G, Gronbaek M. Alcohol consumption and risk of atrial fibrillation in men and women: The Copenhagen City Heart Study. Circulation 2005; 112: 1736-1742.

60. Conen D, Tedrow UB, Cook NR, Moorthy MV, Buring JE, Albert $\mathrm{CM}$. Alcohol consumption and risk of incident atrial fibrillation in women. JAMA 2008; 300: 2489-2496.

61. Sano F, Ohira T, Kitamura A, Imano H, Cui R, Kiyama M, et al. Heavy alcohol consumption and risk of atrial fibrillation: The Circulatory Risk in Communities Study (CIRCS). Circ J 2014; 78: 955 961.

62. Piano MR, Rosenblum C, Solaro RJ, Schwertz D. Calcium sensitivity and the effect of the calcium sensitizing drug pimobendan in the alcoholic isolated rat atrium. J Cardiovasc Pharmacol 1999; 33: 237-242.

63. Pasek M, Bebarova M, Christe G, Simurdova M, Simurda J. Acute effects of ethanol on action potential and intracellular $\mathrm{Ca}(2+)$ transient in cardiac ventricular cells: A simulation study. Med Biol Eng Comput 2016; 54: 753-762.

64. Collart F, de Timary P, Dom G, Dor BD, Duprez D, Lengele JP, et al. Alcohol-induced hypertension: An important healthcare target in Belgium. Acta Clin Belg 2015; 70: 389-395.

65. Zhang EY, Cui L, Li ZY, Liu T, Li GP. High Killips class as a predictor of new-onset atrial fibrillation following acute myocardial infarction: Systematic review and meta-analysis. Chin Med J (Engl) 2015; 128: $1964-1968$.

66. Alonso A, Lopez FL, Matsushita K, Loehr LR, Agarwal SK, Chen LY, et al. Chronic kidney disease is associated with the incidence of atrial fibrillation: The Atherosclerosis Risk in Communities (ARIC) study. Circulation 2011; 123: 2946-2953.

67. Conen D, Tedrow UB, Cook NR, Buring JE, Albert CM. Birth weight is a significant risk factor for incident atrial fibrillation. Circulation 2010; 122: 764-770.

68. Fox CS, Parise H, D’Agostino RB Sr, Lloyd-Jones DM, Vasan RS, Wang TJ, et al. Parental atrial fibrillation as a risk factor for atrial fibrillation in offspring. JAMA 2004; 291: 2851-2855.

69. Cadby G, McArdle N, Briffa T, Hillman DR, Simpson L, Knuiman $\mathrm{M}$, et al. Severity of OSA is an independent predictor of incident atrial fibrillation hospitalization in a large sleep-clinic cohort. Chest 2015; 148: 945-952.

70. Karajamaki AJ, Patsi OP, Savolainen M, Kesaniemi YA, Huikuri H, 
Ukkola O. Non-alcoholic fatty liver disease as a predictor of atrial fibrillation in middle-aged population (OPERA Study). PLoS One 2015; 10: e0142937, doi:10.1371/journal.pone.0142937.

71. O'Neal WT, Lakoski SG, Qureshi W, Judd SE, Howard G, Howard VJ, et al. Relation between cancer and atrial fibrillation (from the REasons for Geographic And Racial Differences in Stroke Study). Am J Cardiol 2015; 115: 1090-1094.

72. Vasan RS, Larson MG, Levy D, Galderisi M, Wolf PA, Benjamin EJ, et al. Doppler transmitral flow indexes and risk of atrial fibrillation (the Framingham Heart Study). Am J Cardiol 2003; 91: 10791083.

73. Chen LY, Leening MJ, Norby FL, Roetker NS, Hofman A, Franco $\mathrm{OH}$, et al. Carotid intima-media thickness and arterial stiffness and the risk of atrial fibrillation: The Atherosclerosis Risk in Communities (ARIC) Study, Multi-Ethnic Study of Atherosclerosis (MESA), and the Rotterdam Study. J Am Heart Assoc 2016; 5: e002907, doi:10.1161/JAHA.115.002907.

74. Tamariz L, Hernandez F, Bush A, Palacio A, Hare JM. Association between serum uric acid and atrial fibrillation: A systematic review and meta-analysis. Heart Rhythm 2014; 11: 1102-1108.

75. Schnabel RB, Larson MG, Yamamoto JF, Sullivan LM, Pencina MJ, Meigs JB, et al. Relations of biomarkers of distinct pathophysiological pathways and atrial fibrillation incidence in the community. Circulation 2010; 121: 200-207.
76. Filion KB, Agarwal SK, Ballantyne CM, Eberg M, Hoogeveen RC, Huxley RR, et al. High-sensitivity cardiac troponin T and the risk of incident atrial fibrillation: The Atherosclerosis Risk in Communities (ARIC) study. Am Heart J 2015; 169: 31 -38.e33.

77. Drca N, Wolk A, Jensen-Urstad M, Larsson SC. Physical activity is associated with a reduced risk of atrial fibrillation in middle-aged and elderly women. Heart 2015; 101: 1627-1630.

78. Mozaffarian D, Psaty BM, Rimm EB, Lemaitre RN, Burke GL, Lyles MF, et al. Fish intake and risk of incident atrial fibrillation. Circulation 2004; 110: 368-373.

79. Aizer A, Gaziano JM, Cook NR, Manson JE, Buring JE, Albert CM. Relation of vigorous exercise to risk of atrial fibrillation. Am J Cardiol 2009; 103: $1572-1577$.

80. Khawaja O, Sarwar A, Albert CM, Gaziano JM, Djousse L. Sleep duration and risk of atrial fibrillation (from the Physicians' Health Study). Am J Cardiol 2013; 111: 547-551.

81. Chamberlain AM, Agarwal SK, Folsom AR, Soliman EZ, Chambless LE, Crow R, et al. A clinical risk score for atrial fibrillation in a biracial prospective cohort (from the Atherosclerosis Risk in Communities [ARIC] study). Am J Cardiol 2011; 107: 85-91.

82. Kokubo Y, Watanabe M, Higashiyama A, Nakao YM, Watanabe T, Takegami M, et al. A Risk score for the prediction of atrial fibrillation in the japanese community: The Suita Study. Circulation 2015; 132: A12264. 